\title{
O PERFIL DO PROFESSOR DE SOCIOLOGIA DA COORDENADORIA REGIONAL DE EDUCAÇÃO DE CANOINHAS/SC
}

\section{ARTIGO ORIGINAL}

WIECZORKIEVICZ, Alessandra Krauss ${ }^{1}$

SANTOS, Adelcio Machado dos ${ }^{2}$

BAADE, Joel Haroldo ${ }^{3}$

WIECZORKIEVICZ, Alessandra Krauss. SANTOS, Adelcio Machado dos. BAADE, Joel Haroldo. O Perfil do professor de Sociologia da Coordenadoria Regional de Educação de Canoinhas/SC. Revista Científica Multidisciplinar Núcleo do Conhecimento. Ano 06, Ed. 01, Vol. 04, pp. 141-166. Janeiro de 2021. ISSN: 24480959, Link de acesso: https://www.nucleodoconhecimento.com.br/educacao/professor-desociologia

${ }^{1}$ Mestre em Desenvolvimento e Sociedade na linha de Pesquisa Desenvolvimento Sociedade e Educação pela UNIARP - Universidade Alto Vale do Rio do Peixe Campus Universitário de Caçador (2019). Possui Bacharel e Licenciatura em Ciências Sociais com Ênfase em Desenvolvimento Regional pela Universidade do ContestadoUNC -Canoinhas (2013), Especialização em Metodologia do Ensino em História e Geografia pelo Centro Universitário Internacional (2014), Especialização em Metodologia do Ensino em Filosofia e Sociologia pela Faculdade de Administração Ciências Educação e Letras (2016) e Licenciatura em filosofia pelo Centro Universitário Internacional (2018). Especialista em Desenvolvimento Regional: Gestão, Economia e Processos produtivos pela faculdade Jangada (2018).

2 Doutorado em Engenharia e Gestão do Conhecimento.

${ }^{3}$ Orientador. Doutorado em Teologia. 


\section{RESUMO}

A Sociologia enquanto componente escolar, tem atributos fundamentais para a construção de uma sociedade melhor, por intermédio da formação de seus alunos. Sua contribuição na sociedade é tema de debates e discussões em diversos contextos sociais. Partindo desse pressuposto, para que a contribuição sociológica aconteça de forma plena na formação dos alunos, a figura do professor de Sociologia entra em destaque. Sendo protagonista na formação de seus alunos. Diante disso, este estudo possui como objeto de pesquisa analisar o perfil dos professores de Sociologia da Coordenadoria Regional de Educação de Canoinhas/SC. Nessa direção, a pesquisa de natureza quantitativa, com questionários fechados foram utilizados para a aplicação de entrevista aos 16 professores de Sociologia. Com o intuito, em compreender o perfil desse professor que está lecionando a disciplina de Sociologia na Coordenadoria. Concluiu-se com esta pesquisa, que o professor da disciplina de Sociologia, leciona além da Sociologia, outras disciplinas para complementar sua carga horária, não se dedicando exclusivamente a preparar e lecionar aulas de Sociologia, desloca-se para os demais municípios da Coordenadoria e não está há muito tempo atuando em sala de aula. A partir dessa análise, é possível entender quem é esse professor e se enfrenta dificuldades no processo de ensino da Sociologia no Ensino Médio.

Palavras-chave: Sociologia, professor, perfil, Ensino Médio.

\section{INTRODUÇÃO}

A reflexão expressa no presente artigo partiu da indagação a respeito do professor de Sociologia de Ensino Médio da Coordenadoria Regional de Educação de Canoinhas/ SC.

O tema foi escolhido, pela importância em compreender o perfil desse profissional da educação. Sua atuação em sala de aula, é fator predominante na construção do conhecimento sociológico, produzido nas aulas de Sociologia no Ensino médio. 
Nessa perspectiva, justifica-se a importância do desenvolvimento desse artigo, que é analisar o perfil desse professor, que está lecionado a disciplina de Sociologia no Ensino Médio na Coordenadoria de Canoinhas. Dessa forma, busca-se o interesse em torno da temática e a importância desse estudo para entender quem é o professor de Sociologia.

A partir daqui o artigo, divide-se em 3 partes. No primeiro momento, será trabalhado com o texto professor de Sociologia. No segundo momento, apresentação da metodologia empregada no artigo. E para finalizar, a exposição dos dados da pesquisa e considerações finais.

\section{PROFESSOR DE SOCIOLOGIA}

O professor é um importante agente de transformação social e também influente na vida escolar de seus alunos. Tem papel na formação e construção social dos indivíduos em sociedade.

Diante disso, Durkheim (1978, p. 23) afirma que "o professor é um grande intérprete das grandes ideias morais de seu país e seu tempo". Com esse direcionamento de transformador e colaborador da sociedade em que está inserido.

Nessa direção, é por intermédio do professor de Sociologia, que o aluno na maioria das vezes é estimulado a pensar, analisar e produzir seu conhecimento sociológico. Rios (2001, p.131) apresenta a importância do professor no contexto social: "Ora, ser professor, séria e rigorosamente, é trazer uma contribuição à descoberta do mundo pelos alunos, é proporcionar crescimento e alegria com a construção e a reconstrução do conhecimento". Libâneo (2012, p. 431) ainda aponta algumas competências do professor enquanto construtor de conhecimento, profissional, responsável pela organização escolar e formação de seus alunos:

O exercício profissional do professor compreende ao menos três atribuições: a docência, a atuação na organização e na gestão da escola e a produção de conhecimento pedagógico. Como docente, necessita de preparo profissional específico para ensinar conteúdos, dar acompanhamento individual aos alunos e proceder à avaliação da 
aprendizagem, gerir a sala de aula, ensinar valores, atitudes e normas de convivência social e coletiva. [...] como profissional que produz conhecimento sobre seu trabalho, precisa desenvolver competências de elaboração e de desenvolvimento de projetos de investigação.

Como vimos, são atributos que fazem parte da atividade do professor no âmbito escolar, enquanto agente de transformação e intermediário na construção do conhecimento. As finalidades do trabalho sociológico em sala de aula são a formação do aluno com capacidades analíticas, interpretativas, argumentativas e conhecimentos para a vivência em sociedade. O professor de Sociologia é a base para essa formação sociológica na plenitude, destacando-se como intermediário na produção do conhecimento, por meio da sinergia que ocorre entre aluno e professor. Essa, é primordial, para a formação e construção do conhecimento sociológico.

Segundo Mills (1975, p. 202), o professor deve utilizar meios para a construção desse conhecimento:

[...] deve começar com o que interessa ao indivíduo mais profundamente, mesmo que pareça trivial e barato. Deve usar materiais e proceder de modo a permitir ao estudante adquirir crescente visão racional de tais preocupações, e de outras que adquirirá no processo de sua educação. E o educador deve tentar desenvolver homens e mulheres que podem, e que por si mesmos o farão, continuar o que ele iniciou: o produto final de qualquer educação libertadora é simplesmente o homem. [...] indivíduo livre e racional.

O professor de Sociologia, deve ser um profissional consciente de suas atribuições, com conhecimento nas diversas metodologias educacionais, conhecendo as teorias sociológicas, entendendo a realidade social da escola na qual leciona, compreendendo seus alunos e quais as formas de como trabalhar com eles em sala de aula, para assim desenvolverem o conhecimento sociológico.

Todavia, alguns desafios apresentam-se na trajetória da formação sociológica: a falta de uma identidade própria da disciplina, decorrente do processo de suas idas e vindas no currículo obrigatório e a formação dos professores da área de Sociologia. A esse respeito, Jinkings (2013, p. 107) apresenta: 
[...] os desafios postos para que se desenvolvam efetivamente as potencialidades educativas das ciências sociais nas escolas são muitos e complexos. A trajetória intermitente da disciplina de Sociologia no sistema escolar e sua débil tradição pedagógica demandam uma continuidade e um aprofundamento da discussão coletiva sobre as finalidades formativas da disciplina e suas possibilidades didáticas, tanto nos espaços acadêmicos, como nas escolas.

Durante todo o processo da inserção da sociologia nos currículos escolares, muitas foram as motivações que ocasionaram a não existência de uma identidade da disciplina de Sociologia na escola, como: ausências ou limites de concepções de sua finalidade, métodos e conteúdos A mudança para o caráter obrigatório apresenta para a Sociologia o desafio de encontrar seu lugar e ganhar características próprias no ensino médio, assim como ocorrido com outras disciplinas historicamente consolidadas (RUSSCZYK; LEITÃO, 2012). A Sociologia ainda enfrenta muitos desafios, em busca de uma identidade escolar.

É notório que a Sociologia, enquanto disciplina, é recente e ainda vem evoluindo e conquistando espaços no âmbito escolar, principalmente no ensino médio. Porém, desde sua obrigatoriedade em 2008, muitos paradigmas foram rompidos e estão sendo superados, mas ainda não é o suficiente para que esse componente curricular seja considerado importante e necessário na formação do aluno. Nesse aspecto, " a disciplina traz novos desafios interpretativos sobre os resultados, os direcionamentos e em quais condições a Sociologia vem sendo colocada em prática" (RAIZER et al., 2017, p. 16).

Nessa direção, " o processo de implantação da Sociologia nas diferentes regiões e estados do país, conforme estudos tem mostrado, caracteriza-se por uma pluralidade de cenário" (CAREGNATO; CORDEIRO, 2014, p. 46). Nessa perspectiva, Russczyk e Leitão (2012, p. 08), destacam a ausência da formação plena do professor de Sociologia, como um dos problemas que a disciplina ainda enfrenta na prática diária nas escolas. Vejamos:

Os números relacionados à quantidade de professores que hoje ministram aulas de sociologia demostram a grande necessidade de adequar a formação desses professores à nova exigência legal. [...] 
propostas curriculares em sociologia discutidas e formuladas por professores cuja grande maioria não possui formação específica em Sociologia.

Nesse aspecto, Mota (2005, p. 103) apresenta que:

[...] grande parte das escolas não são os profissionais da área que lecionam sociologia. Outras concepções, portanto, que não a sociológica, sobressaem conforme a formação universitária do docente que ministra a disciplina. A repercussão disso no ensino para os estudantes, possivelmente, é uma visão fragmentada e teoricamente confusa da própria sociologia.

Bodart e Silva (2016, p. 178) ainda destacam que:

[...] a disciplina de Sociologia não é ministrada apenas por professores licenciados em Ciências Sociais/Sociologia. Há uma deficiência muito grande nesse aspecto, 0 que pode estar comprometendo significativamente a maior consolidação dessa disciplina no currículo escolar do Ensino Médio.

De acordo com os posicionamentos dos autores, a disciplina de Sociologia passa por situações conflitantes, que refletem no trabalho dos docentes em sala de aula. $O$ processo conturbado da inserção do componente escolar nos currículos escolares, por exemplo, dificultou sua conquista identitária e a formação dos professores que lecionam Sociologia.

Todo esse processo afeta o ensino da Sociologia, pelo fato de como a comunidade escolar e a sociedade consideram a importância da Sociologia no meio escolar e a visão referente ao trabalho dos professores da disciplina. Além dos conflitos de ordem cultural, há também a questão da formação do professor que leciona a disciplina, situação preocupante que é revelada nas pesquisas[4], que na grande maioria das escolas brasileiras são professores de outras áreas de conhecimento que atuam nas aulas de Sociologia.

De acordo com Silva (2007, p. 422), "o papel da sociologia na formação dos adolescentes e dos jovens dependerá do tipo de escola, do ensino médio e do currículo que iremos definir ao longo da história". Toda a construção do conhecimento 
sociológico, no ensino médio, está relacionada com a atuação do professor em sala de aula e o interesse dos alunos envolvidos no processo.

É importante que o professor da disciplina consiga desenvolver as teorias sociológicas, fortalecendo a Sociologia enquanto disciplina, usando as metodologias adequadas para o ensino e contribuindo com a formação de seus alunos para a vivência em sociedade.

\section{METODOLOGIA}

O objetivo desta parte do artigo é apresentar a metodologia utilizada, demonstrando os processos que foram adotados no desenvolvimento da pesquisa, permitindo a visualização dos passos que permitiram o desenvolvimento do trabalho.

Neste primeiro momento empregou-se a técnica de análise documental, isto é, a utilização de fontes secundárias, como livros, jornais, dissertações para o desenvolvimento do referencial teórico (LAKATOS, 2010). É importante mencionar que os materiais para a elaboração do texto o professor de Sociologia, foram livros clássicos da Sociologia, dissertações, teses, artigos científicos, documentos educacionais, bases de dados de Sociologia e ciências sociais, periódicos da Scielo, da Coordenação de Aperfeiçoamento de pessoal de Nível Superior (CAPES).

A partir da pesquisa bibliográfica e utilização da técnica documental, passou-se para a pesquisa de campo, classificada como quantitativa, através da qual foi investigada o perfil dos professores de Sociologia na Coordenadoria Regional de Educação de Canoinhas. A pesquisa de campo, segundo Lakatos (2001, p. 83),

[...] é aquela utilizada como objetivo de conseguir informações e /ou conhecimentos acerca de um problema para o qual se procura uma resposta, ou de uma hipótese que se queira comprovar, ou, ainda, descobrir novos fenômenos ou as relações entre eles. Consiste na observação de fatos e fenômenos tal como ocorrem espontaneamente, na coleta de dados a eles referentes e no registro de variáveis que se presume relevantes, para analisá-los. 
Nessa etapa da pesquisa, fez-se um trabalho de campo, visitando-se todas as escolas da Coordenadoria e, realizando as entrevistas com os professores de Sociologia, com a utilização dos questionários.

\section{RESULTADOS E ANÁLISE}

Foi realizado uma pesquisa quantitativa nas instituições escolares localizadas nos seis municípios da Coordenadoria, totalizando 19 escolas Estaduais pesquisadas.

Quadro 1 - Escolas pesquisadas

\begin{tabular}{|c|c|}
\hline Município & Escola \\
\hline Porto União & $\begin{array}{l}\text { E.E.B. Cid Gonzaga, E.E.B. Nilo Peçanha, E.E.B. Clementino } \\
\text { Britto, E.E.B. Antônio Gonzaga, E.E.B. Bauduíno Cardoso e E.E.B. } \\
\text { Germano Wagenfurh. }\end{array}$ \\
\hline Irineópolis & E.E.B. Horácio Nunes \\
\hline $\begin{array}{l}\text { Bela Vista do } \\
\text { Toldo }\end{array}$ & E.E.B. Estanislau Schumann \\
\hline Major Vieira & E.E.B Luiz Davet \\
\hline Canoinhas & $\begin{array}{l}\text { E.E.B. Almirante Barroso, E.E.B. Irmã Maria Felicitas, E.E.B. Julia } \\
\text { Baleoli Zaniolo, E.E.B. Prof. Manoel da Silva Quadros, E.E.B. } \\
\text { Rodolfo Zipperer, E.E.B. Santa Cruz e Cedup Vidal Ramos. }\end{array}$ \\
\hline Três Barras & $\begin{array}{l}\text { E.E.B. Colombo Machado Salles, E.E.B. Frei Menandro Kamps e } \\
\text { E.E.B. General Osório. }\end{array}$ \\
\hline
\end{tabular}

Fonte: Autora (2019)

Em relação aos procedimentos adotados para a pesquisa, a pesquisadora entrou em contato com todas as escolas estaduais, conversou com os professores de Sociologia, referente aos objetivos da pesquisa e convidou-os para participarem da pesquisa. Com o convite feito e aceito, foram realizados agendamentos, para que assim a pesquisadora se desloca até as escolas, no melhor horário possível para os professores, com a finalidade de realizar a entrevistas. 
A entrevista foi realizada por meio de questionário com 16 questões fechadas sobre $o$ perfil do professor.

\section{PERFIL DO PROFESSOR DE SOCIOLOGIA DA COORDENADORIA REGIONAL DE EDUCAÇÃO DE CANOINHAS/SC}

Apresentam-se algumas informações direcionados ao perfil dos professores da disciplina de Sociologia, atuantes em sala de aula no ano de 2019. Considerando os 16 professores participantes, observa-se que predominantemente a maioria são homens equivalente a 10 professores, e 6 professoras.

Gráfico 1 - Sexo dos participantes

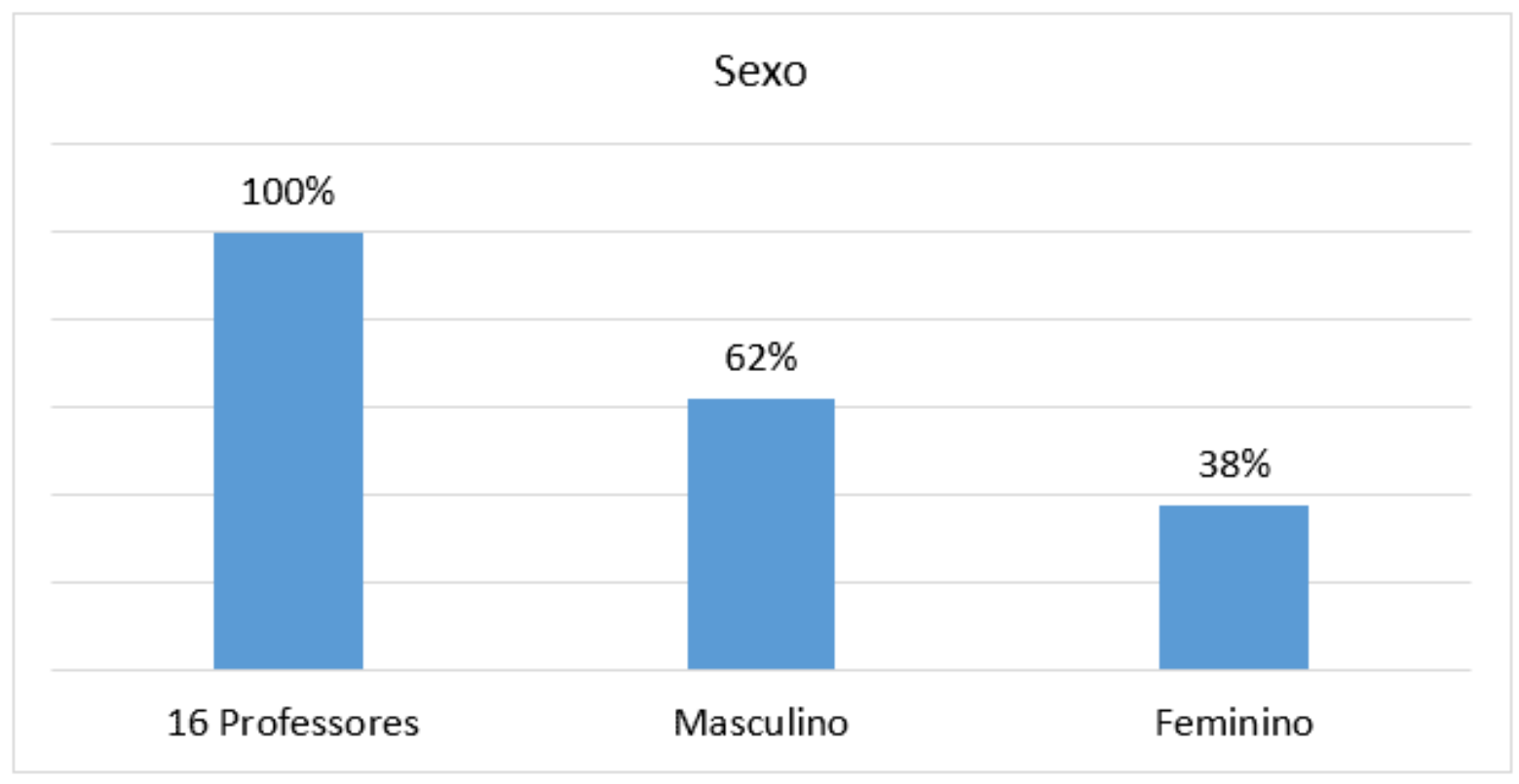

Fonte: dados da pesquisa (2019)

A pesquisa também revelou que há um perfil com uma certa maturidade, com idade média de 35 anos, predominando a maioria com 35 a 45 anos. O professor mais jovem tem entre 18 e 25 , e o mais velho entre 55 ou mais anos. 
Gráfico 2 - Idade dos professores

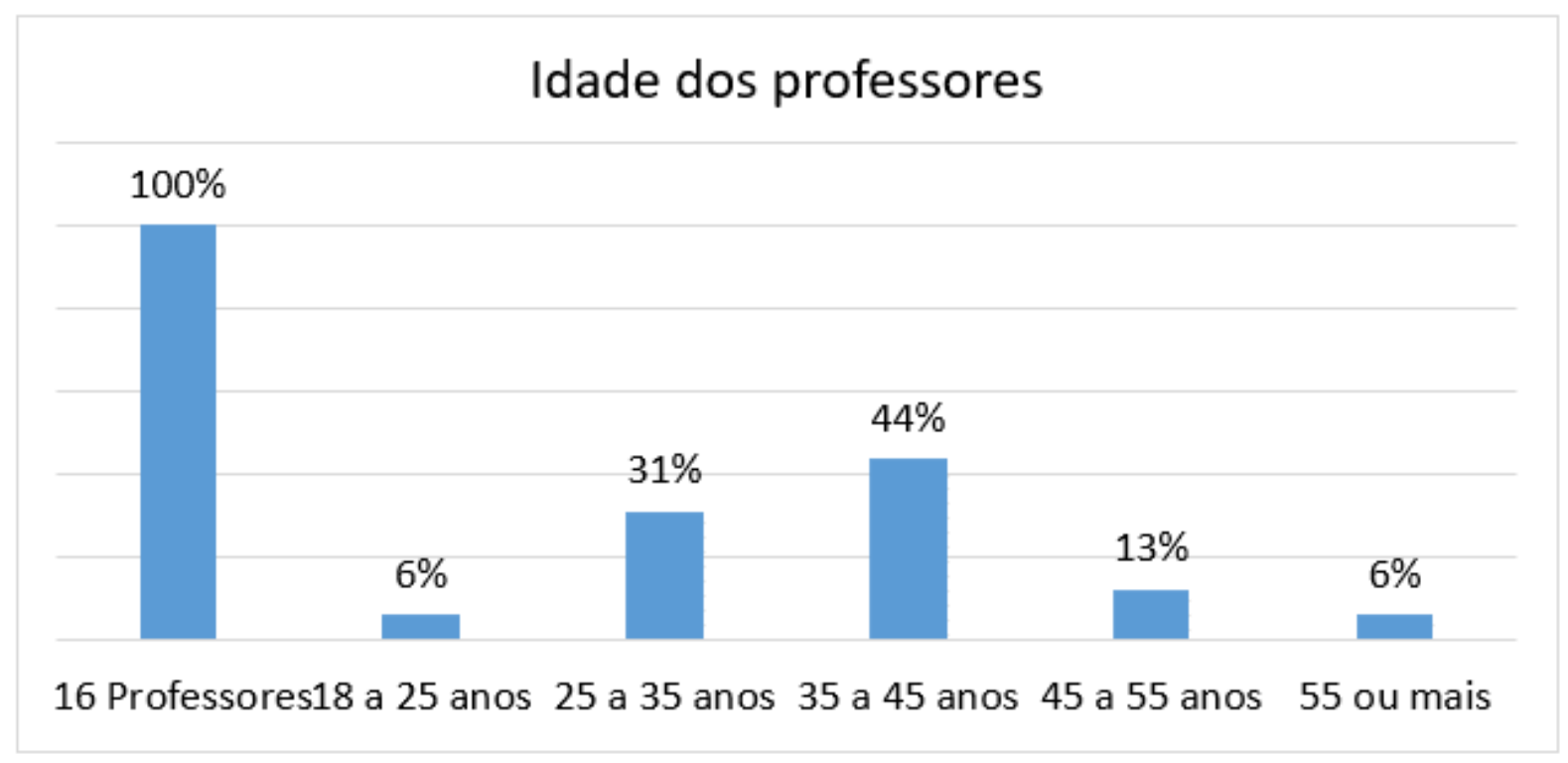

Fonte: dados da pesquisa (2019)

Em relação ao local em que residem esses professores, é destacado que os professores que trabalham nos municípios com o maior número de escolas, residem também no município. Os demais professores, que lecionam nos municípios menores, se deslocam até esses municípios para trabalhar. 
Gráfico 3 - Reside em que município

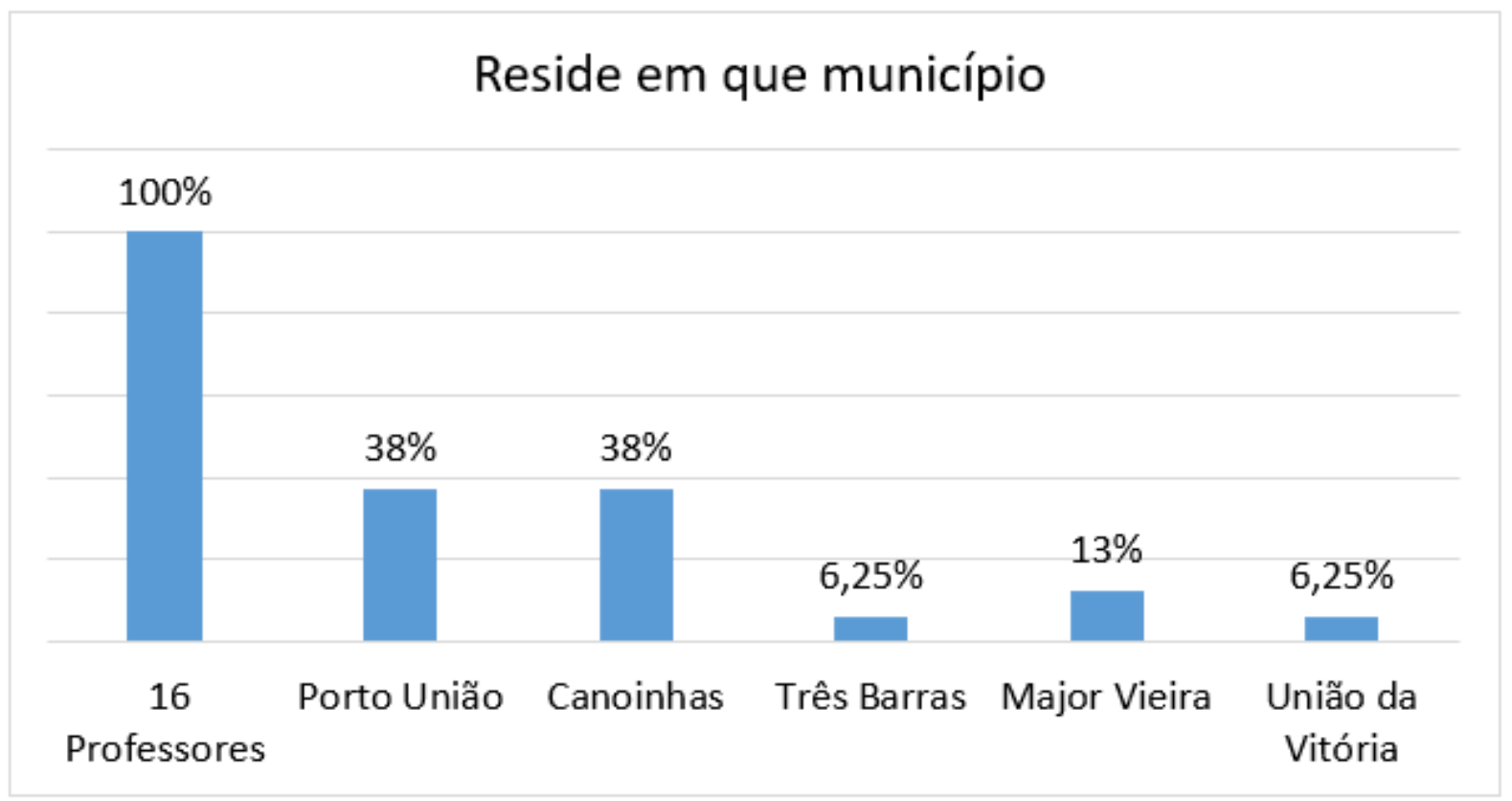

Fonte: dados da pesquisa (2019)

Em relação à formação dos professores de Sociologia, dos 16 entrevistados, 12 professores têm formação plena em Ciências Sociais/Sociologia, os demais têm formação em outras áreas como: Filosofia, História, Geografia, Pedagogia e Magistério.

O dado mostra a evolução da formação na disciplina, pois na grande maioria das vezes a disciplina era lecionada por professores de outras formações. Esse dado é apresentado nas pesquisas realizadas em 2012, 2013 e 2014 sobre o perfil dos professores de Sociologia no Brasil.

O certo é que atualmente a disciplina de Sociologia não é ministrada apenas por professores licenciados em Ciências Sociais/Sociologia, o que é evidenciado por esta pesquisa, que explicita como percentual de licenciados em Sociologia/Ciências Sociais apenas 61,3\%. Há uma deficiência muito grande nesse aspecto, 0 que pode estar comprometendo significativamente a maior consolidação dessa disciplina no currículo escolar do Ensino Médio (BODART e SILVA, 2016, p. 178). 
Esse dado, também é apresentado em outra pesquisa, sobre o perfil desse professor no Brasil

Entre os doze componentes curriculares do ensino médio, a disciplina de Sociologia é a que apresenta a maior incidência de professores não graduados na área: em 2013, observa-se que 88, 2\% não tem formação específica (RAIZER et al., 2017, p.24).

Nesse direcionamento, em 2014 foi realizada uma pesquisa no estado do Rio Grande do Sul, relacionado ao professor de Sociologia.

A realidade no caso do RS evidencia que, ainda em 2014, quem leciona as disciplinas de sociologia no ensino médio são majoritariamente professores formados em áreas distintas das ciências sociais. Não se pode negar que a maior parte dos professores que ministram sociologia nas escolas gaúchas não tem formação de origem na área, sobretudo em razão de problemas relacionados à distribuição de encargos nas escolas e também a continuidade de escassez de profissionais (MOCELIN e RAIZER, 2014, p.123-124).

É importante destacar, que essas pesquisas têm o objetivo de compreender o perfil do professor que ministra Sociologia, e apresentam que a maioria dos professores de Sociologia não são licenciados na área. Esses dados são relacionados a pesquisas feitas nos anos de 2012, 2013 e 2014.

Porém, em 2019, esse não é o cenário que se apresenta na Coordenadoria Regional de Educação de Canoinhas, levando em consideração que a maioria dos professores que lecionam sociologia têm a formação na área. Contudo, a Coordenadoria ainda apresenta, 4 professores com formação em outras áreas. Isto, é ainda um desafio a ser superado, porém se comparado com as pesquisas mencionados no texto, a tendência é eliminar esses números de professores não licenciados em Sociologia, em uma realidade não tão distante. 
Gráfico 4 - Formação dos professores

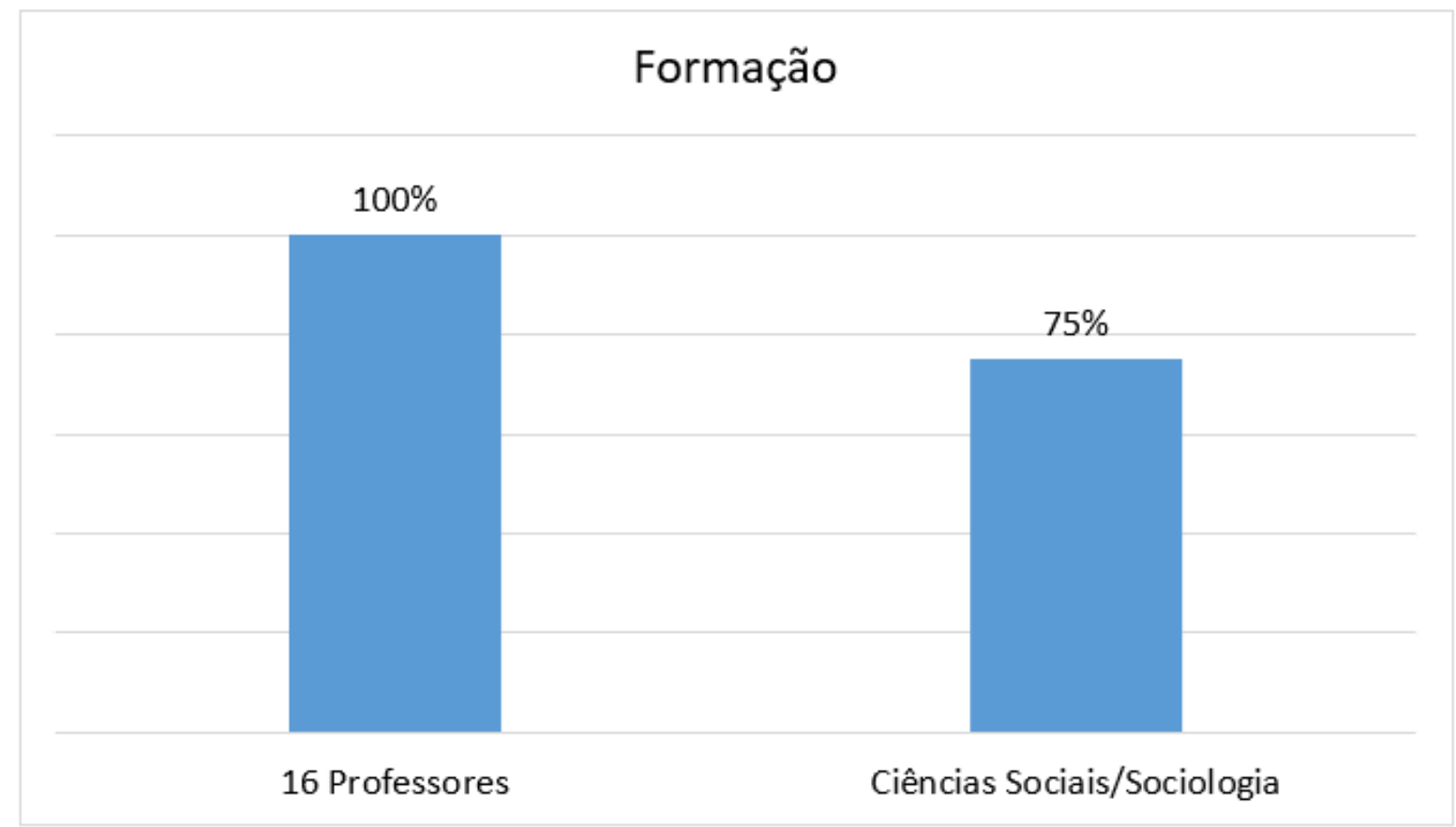

Fonte: dados da pesquisa (2019)

Outro dado importante, na formação desses professores, é que além da formação em Sociologia/ Ciências Sociais, também são formados em outras disciplinas. Sendo, 6 professores formados em filosofia, 5 professores em História, 2 professores em Geografia, 1 professor em pedagogia e 1 professor em magistério. Dos 16 professores, somente 1 professor tem a formação em Ciências Sociais.

Esse dado dos professores que lecionam sociologia, com formações em outras disciplinas, também foram apresentados em outras pesquisas. Os autores Bodart e Silva (2016, p. 177) apresentaram em sua pesquisa que o percentual de pedagogos e graduados em História é bastante significativo. Outra pesquisa demostra a mesma situação, "A formação dos professores que leciona Sociologia [...] com destaque para professores com diversas formações superiores (44\% do total), seguido por licenciados em História (20\%), Pedagogia (12\%), e Filosofia" (10\%) (RAIZER et al., 2017, p. 19) 
A pesquisa, realizada em 2014, pelos autores Mocelin e Raizer (2014, p. 114), apontou várias formações de professor atuando em Sociologia "destacam-se aqueles com em outras áreas (31\%), como Pedagogia, Letras, Direito, Teologia, Psicologia. Os que possuem formação em Ciências Sociais e áreas afins concentram-se em História (27\%) [...] Filosofia (10\%), Geografia (6,5\%), e Estudos Sociais (2\%)".

De acordo com as pesquisas realizadas, ainda é consistente a informação que professores que lecionam a Sociologia possuem outras formações além das Ciências Sociais, ou somente outra formação e não a sociológica.

Gráfico 5 - Outras formações dos professores

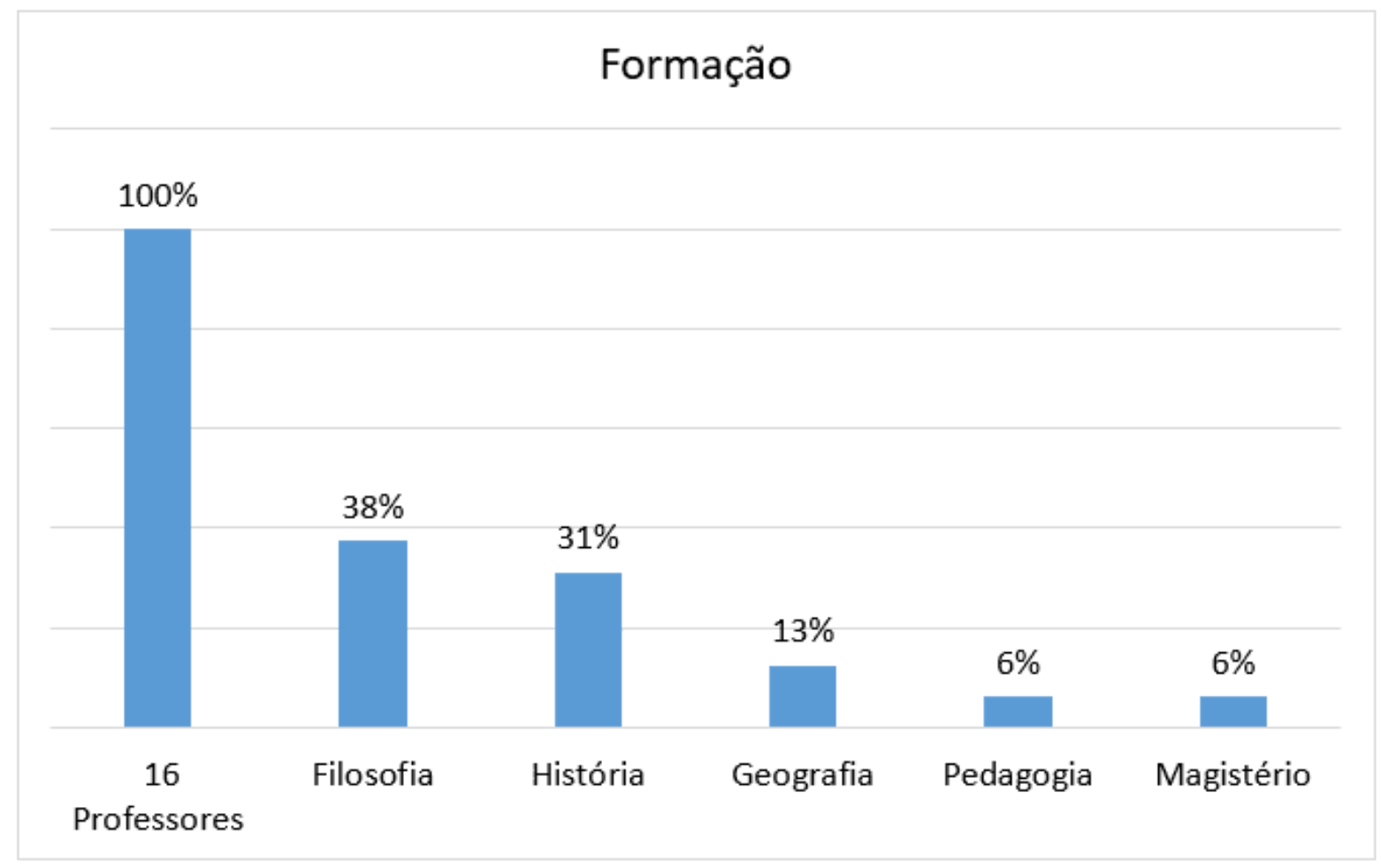

Fonte: dados da pesquisa (2019)

Quando perguntado sobre especialização, 14 professores têm especialização, 1 não tem e 1 está cursando. 
Ainda na formação dos professores, quando questionado sobre o mestrado, destacouse que se apresenta um número mínimo de professores com mestrado: 4 professores mestres, 2 não responderam, 1 está cursando e 9 não tem mestrado.

Entre os professores entrevistados destaca-se que não há doutores lecionando Sociologia na Coordenadoria Regional de Educação de Canoinhas, 13 professores responderam que não tem doutorado, e 3 não responderam à questão.

Tabela 2 - Formação Continuada

\begin{tabular}{|c|c|c|}
\hline Especialização & Mestrado & Doutorado \\
\hline 14 professores especialistas & 4 professores mestres & $\begin{array}{ll}\text { Não } & \text { há } \\
\text { doutores }\end{array}$ \\
\hline 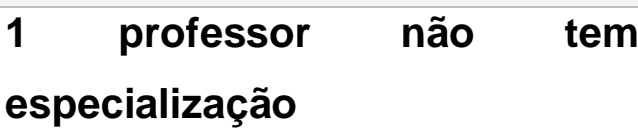 & $\begin{array}{l}9 \text { professores não têm } \\
\text { mestrado }\end{array}$ & \\
\hline 1 professor está cursando & 1 professor está cursando & \\
\hline
\end{tabular}

Fonte: dados da pesquisa (2019).

As pesquisas realizadas, sobre o perfil desse professor de Sociologia, apresentaram uma deficiência na formação complementar, direcionadas a nível de mestrado e doutorado. Essa conclusão foi apresentada, quando perguntada na pesquisa de Raizer et al, (2017, p 21) referente a formação continuada dos professores de Sociologia "visando à formação continuada de professores em serviço está bastante aquém do esperado". Na pesquisa de Bodart e Silva (2016, p. 179), essa informação é expressiva também.

[...] é possível perceber que a maioria $(42,5 \%)$ dos professores de Sociologia questionados que atuam no Ensino Médio não tem nenhuma formação complementar. [...] esses dados evidenciam, somados ao grande percentual de professores de Sociologia[...] a deficiência na formação, sobretudo, na formação continuada dos que lecionam Sociologia no Ensino Médio. Em síntese, aferimos que além, da deficiência da profissionalização inicial, existem limitações no que concerne à formação continuada do professor de Sociologia. 
Percebe-se que, essa dificuldade de formação complementar não é somente um problema dos professores de Sociologia da Coordenadoria Regional de Educação de Canoinhas, mas sim de todas as regiões do país.

Outra questão abordada, é sobre a atuação dos professores no magistério, e destacou-se, como mediano, pois é bem dividido, fatores que podem decorrer da faixa etária dos professores e sua iniciação nas atividades de docência dentro do magistério. Observa-se que 4 professores estão no magistério entre 1 a 5 anos, e outros 4 entre 15 a 20 anos, não sendo professores que estão a muito tempo no magistério. Outros 3 professores estão entre 5 a 10 anos e mais 3 entre 20 anos ou mais.

Gráfico 6 - Tempo de trabalho dos professores no Magistério

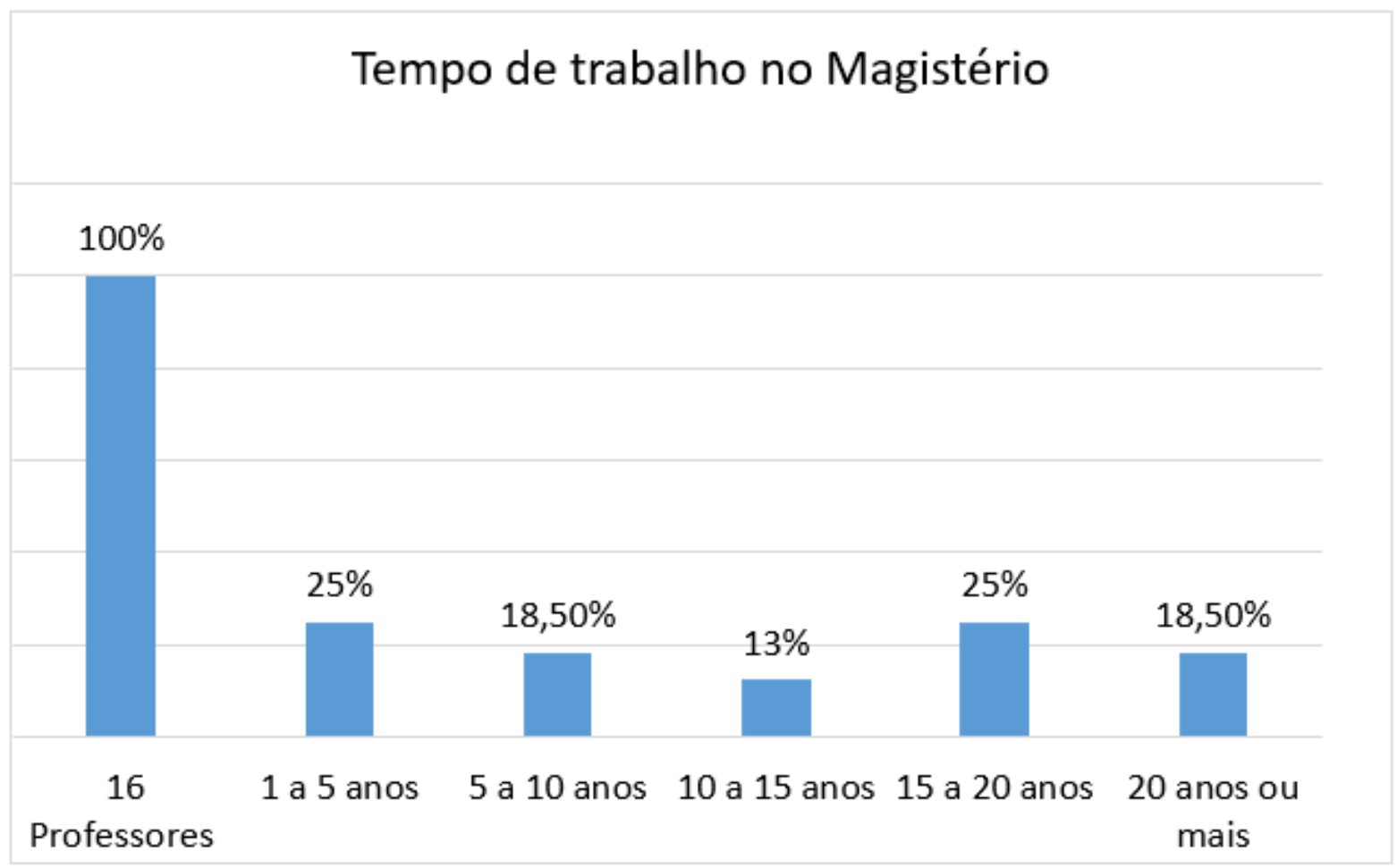

Fonte: dados da pesquisa (2019)

Durante o período no magistério, esses professores de Sociologia, lecionaram outras disciplinas. Sendo que 11 professores já lecionaram Filosofia, 7 História, 6 Geografia, 
2 artes, 1 Ensino religioso, 1 Inglês, 1 Química, 1 Psicologia, 1 Educação Física, 1 Língua Portuguesa, 1 trabalhou como pedagoga e 1 não respondeu à questão.

Gráfico 7 - Outras disciplinas que o professor lecionou no magistério

\section{Outras disciplinas que lecionou durante sua atuação no magistério}

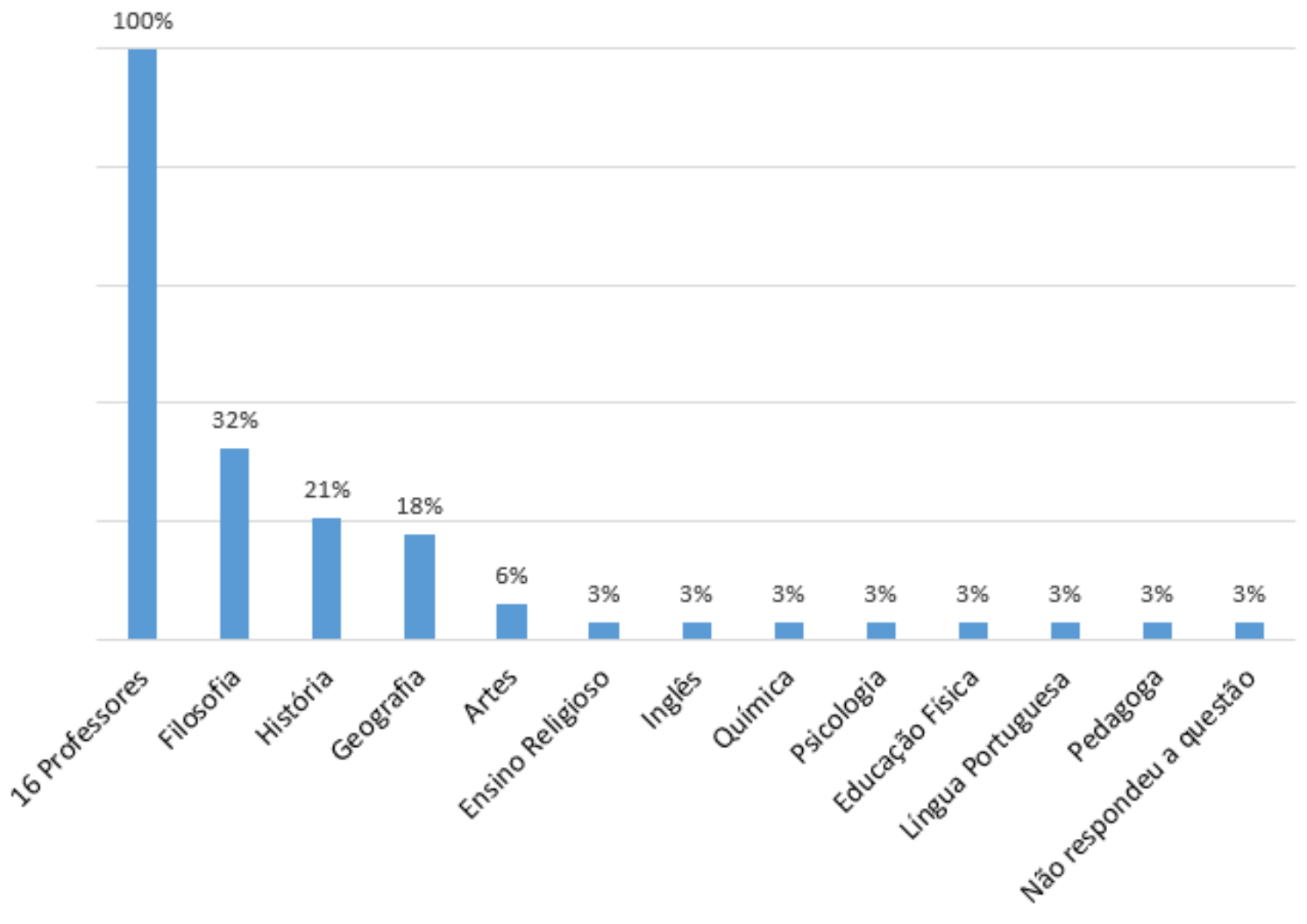

Fonte: dados da pesquisa (2019)

No que se refere ao tempo de magistério em Sociologia, cabe destacar que parece, que a maioria dos professores leciona sociologia a pouco tempo, pois, 6 professores lecionam sociologia no período de tempo de 1 a 5 anos. Apenas, 4 professores lecionam a mais de 10 a 15 anos, 3 lecionam de 15 a 20 anos, 2 professores de 20 a mais anos e somente 1 professor no período de 5 a 10 anos. Levando em consideração todos esses dados, não faz muito tempo que a maioria desses 
professores lecionam a disciplina de Sociologia. Essa diferença de tempo, referente a atuação entre os professores, é apresentada também em outra pesquisa.

Na pesquisa de Mocelin e Raizer (2013, p. 115), é identificado o tempo de atuação dos professores em Sociologia.

No que se refere ao tempo de atuação como professor de sociologia no ensino médio, percebe-se que $67,5 \%$ dos respondentes lecionam a disciplina há até 5 anos, dado que condiz com a Lei da obrigatoriedade. A maior parte dos respondentes atua há menos de um ano como professor de sociologia no ensino médio (27,3\%); sendo que $26 \%$ atuam entre 1 e 3 anos e $14,3 \%$ atuam entre 3 e 5 anos com a disciplina de sociologia. Apenas $14 \%$ atua há mais de 5 anos, sendo que apenas $4 \%$ atua há mais de 10 anos.

Se compararmos os dados da pesquisa apresentada, com os dados da Coordenadoria, percebe-se que não há diferenças de tempo, e que a maioria desses professores não está atuando a muito tempo em Sociologia.

Gráfico 8 - Tempo como professor de Sociologia

\section{Tempo como professor de Sociologia}

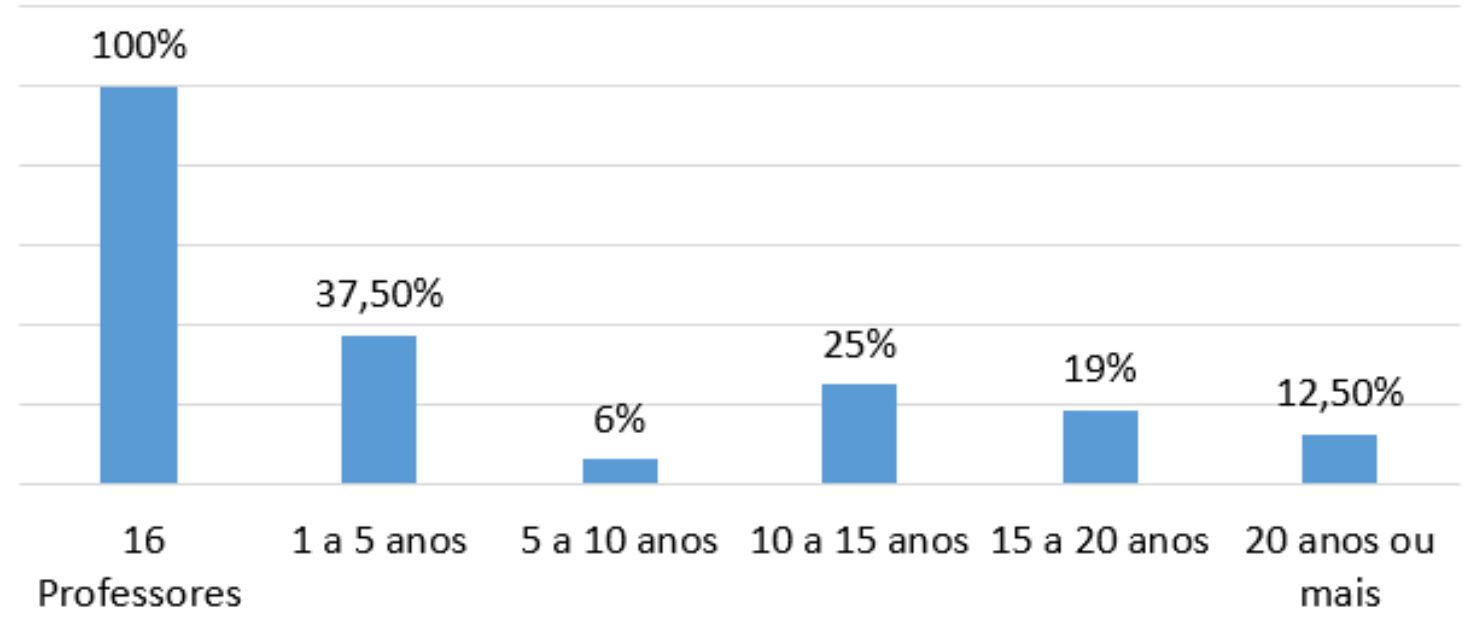

Fonte: dados da pesquisa (2019) 
Na coordenadoria Regional de Educação de Canoinhas, destacam-se: 10 professores efetivos e 6 professores ACT. A grande maioria já pertence ao quadro de funcionários públicos estatuários.

Gráfico 9 - Tipo de vínculo dos professores com o Estado de Santa Catarina

\section{Tipo de Contrato}

$100 \%$

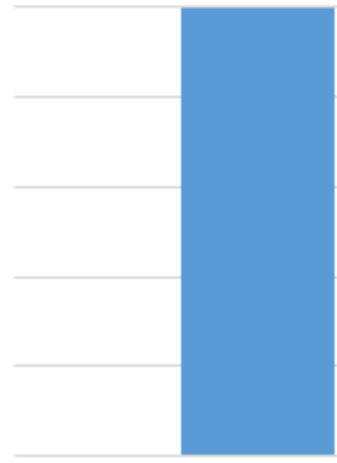

16 Professores
$63 \%$

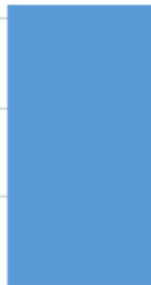

São efetivos
$37 \%$

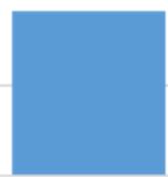

São ACTs

Fonte: dados da pesquisa (2019)

Quando perguntado aos professores sobre em quantas escolas trabalham Sociologia, 8 professores responderam que trabalham em duas escolas, 7 em 1 escola e 1 em três escolas.

Essa realidade, também foi apresentada na pesquisa de Bodart e Silva (2016, p. 186).

[...] $46,55 \%$ dos professores trabalham em duas ou mais escolas, percentual considerável preocupante. Tendo que revezar entre duas ou mais escolas, seu desempenho pode ficar prejudicado por vários fatores, tais como a diferença entre a cultura organizacional da escola, a perda de tempo em deslocamento e o maior número de planos diversificados de acordo com realidades diferentes dos educandos.

Esse dado, é igualmente expressivo na pesquisa de Raizer et al., (2017, p.19), quando perguntado aos professores sobre atuação em escolas, " $58,9 \%$ atuam em duas ou mais escolas. 
Demonstra-se que essa não é somente a realidade de trabalho dos professores da Coordenadoria, mas um dado refletido em todo o país. Ou seja, a necessidade de deslocamento e atuação em mais de uma escola, para complementação de carga horária.

Gráfico 10 - Número de escolas que os professores trabalham

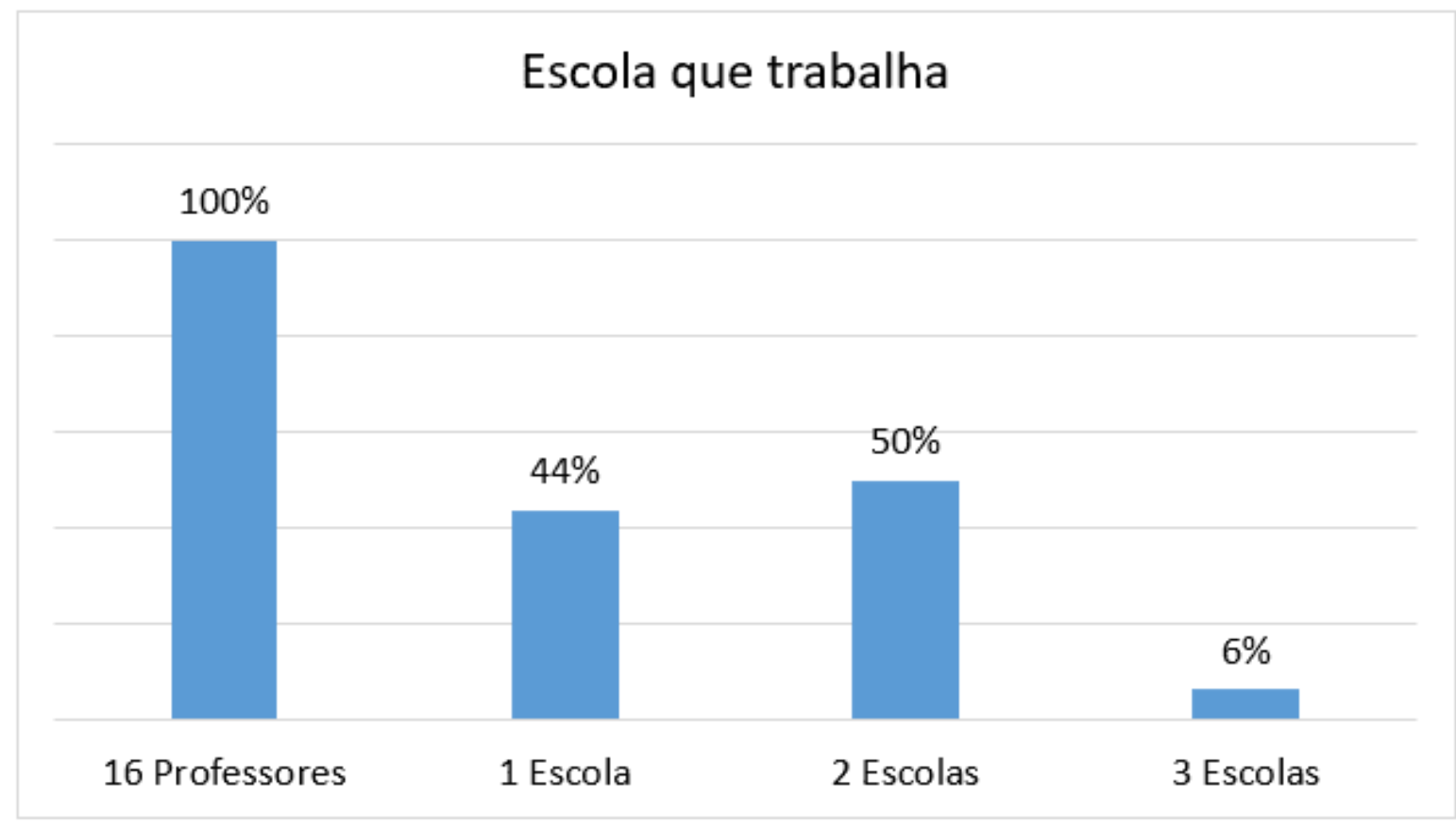

Fonte: dados da pesquisa (2019)

Em relação ao trabalho nas escolas do mesmo município, 14 professores trabalham no mesmo município, e somente 2 precisam deslocar-se para outra cidade.

No que cabe a esses 14 professores que trabalham no mesmo município, eles atuam nos dois maiores municípios da Coordenadoria, onde um município conta com 6 escolas e o outro com 7, sendo os maiores números de aulas de sociologia. Esses 2 professores que, deslocam-se por mais de um município para trabalhar, são nos dois menores municípios da Coordenadoria. 
Gráfico 11 - Município em que os professores trabalham

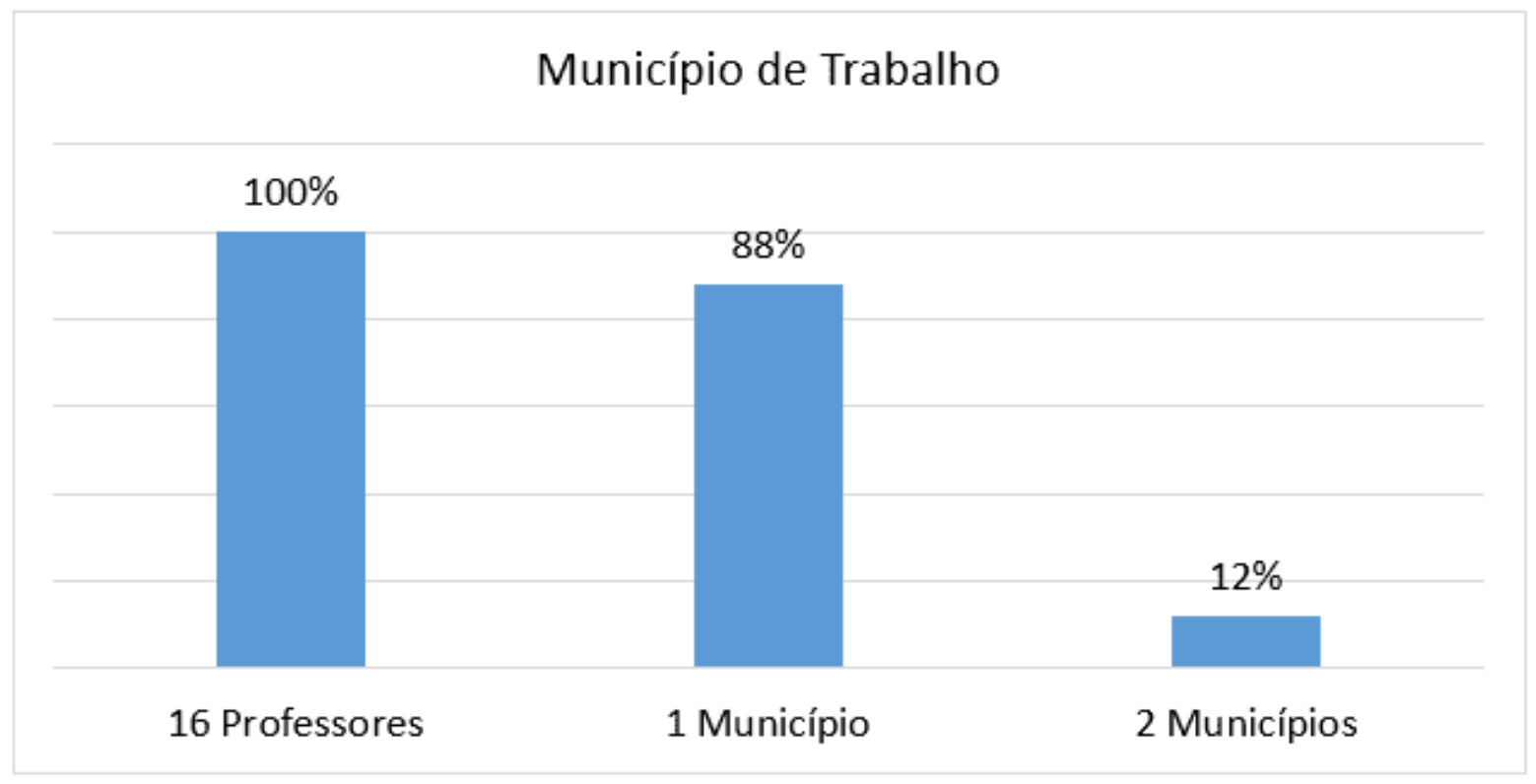

Fonte: dados da pesquisa (2019)

Entre os 16 professores de Sociologia, 7 tem carga horária de 40 horas, os outros 9 professores complementam sua carga com outras disciplinas. Sendo essa uma realidade apresentada nas pesquisas, que foram feitas sobre o professor de Sociologia. Os autores Mocelin e Raizer (2014, p. 116) identificaram essa informação:

[...] são muito poucos as que ministram apenas sociologia. Entre os 154 professores respondentes da pesquisa, apenas nove deles dedicam-se exclusivamente ao ensino da sociologia (6\%), sendo que destes nove, oito são licenciados em ciências sociais. [...] a maior parte dos professores respondentes dedica-se ao ensino de pelo menos outras duas disciplinas, além da sociologia $(30 \%)$. Esse dado pode mostrar certa sobrecarga de trabalho dos professores, o que pode colocar em risco a qualidade do ensino da sociologia. É provável que o professor de outras disciplinas esteja completando sua carga horária com um ou dois períodos de sociologia.

Os autores Raizer et al. (2017, p. 19), também constataram essa informação em sua pesquisa.

Para além da constatação da demanda de professores, observa-se que "o professor típico de Sociologia do ensino médio regular leciona outra (s) disciplina (s) e não é exclusivo dessa etapa de ensino". Dos 47.961 
professores de Sociologia do país, apenas 12,7\% dedicam-se exclusivamente ao ensino dessa disciplina.

Essa é a realidade da Coordenadoria, juntamente com todo o país. Todas as pesquisas mencionadas alcançam a mesma conclusão, direcionada a atuação do professor de Sociologia, que complementa sua carga horária de trabalho com outras disciplinas, sem dedicação exclusiva ao ensino na área.

Gráfico 12 - Carga horária semanal dos professores

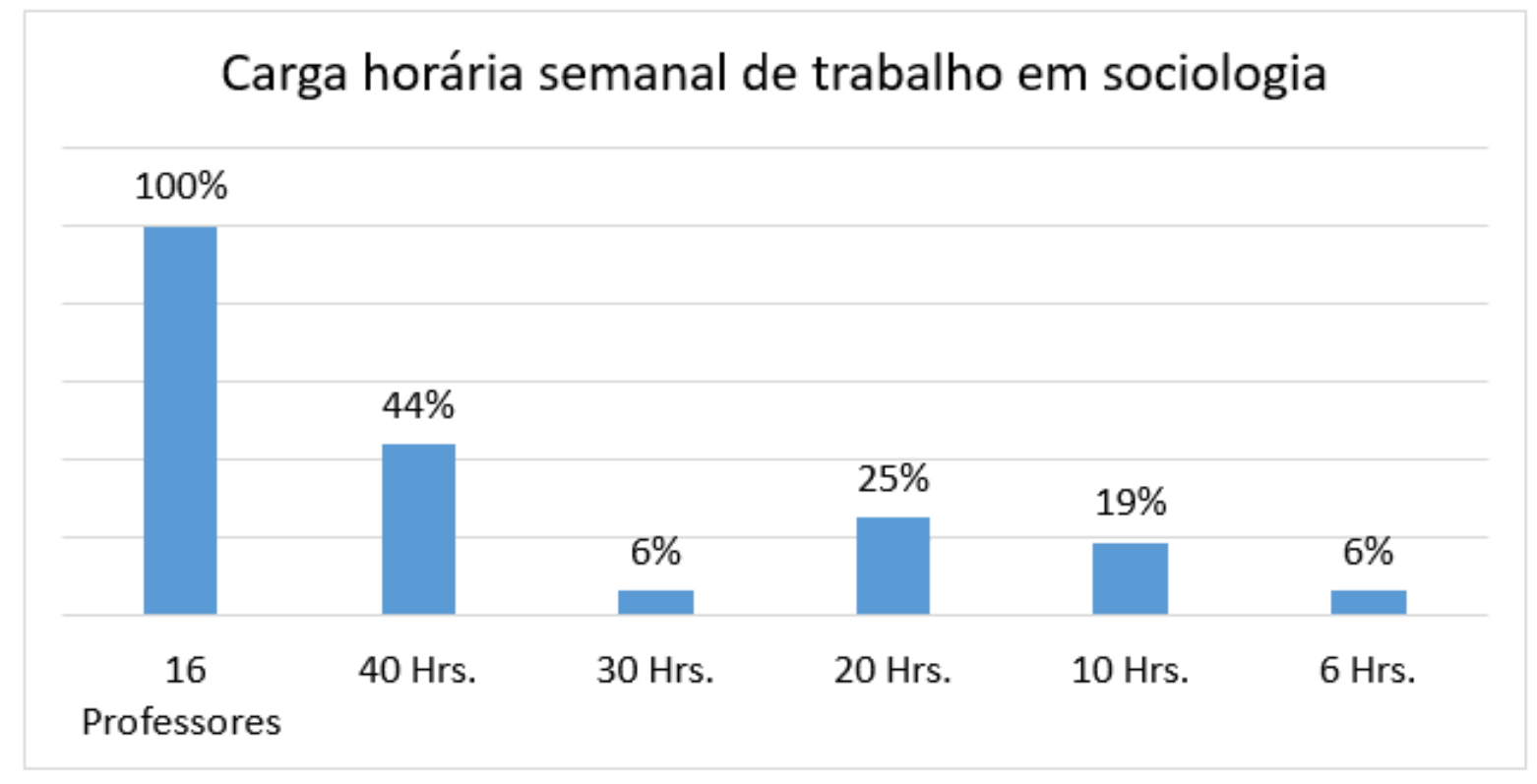

Fonte: dados da pesquisa (2019)

$\mathrm{Na}$ Coordenadoria Regional de Educação de Canoinhas, as disciplinas que são lecionadas juntamente com a Sociologia pelos docentes são: Filosofia com 6 professores, História com 4 professores e 1 professor de Geografia.

Essas disciplinas, são lecionadas em outras regiões do país por professores que trabalham com Sociologia, é o que diz a pesquisa de Mocelin e Raizer (2014, p. 116), "As disciplinas que mais são lecionadas concomitantemente à sociologia pelos professores respondentes são História (19\%), Filosofia (12\%), Seminário Integrado (7\%), Religião (6\%), Ética (1,3\%)".

Outra pesquisa também apresenta dados pertinentes a esta questão. 
Entre os docentes que lecionam outras disciplinas, ganha destaque os que lecionam Filosofia, entre os que atuam apenas no ensino médio; já entre os que atuam também em outros níveis de ensino, destaca-se a disciplina de História como a mais lecionada concomitantemente com a de Sociologia (RAIZER et al., 2017, p.19).

Essa realidade enfrentada pelos professores de sociologia, é visível nas pesquisas sobre seu perfil e também na Coordenadoria Regional de Educação em Canoinhas.

Gráfico 13 - Disciplinas que os professores lecionam além da sociologia

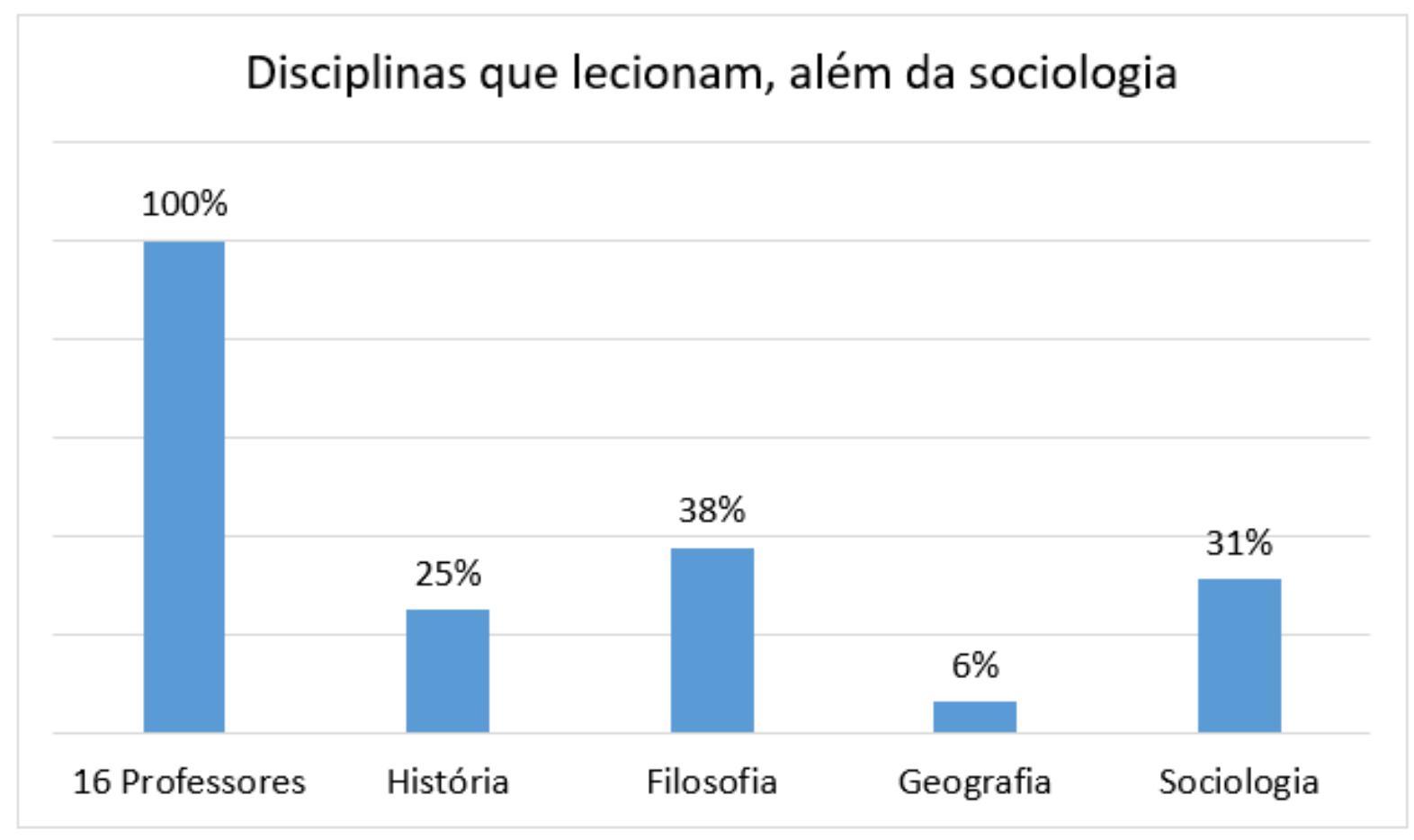

Fonte: dados da pesquisa (2019)

No que se refere as séries trabalhadas, 14 professores atuam na $1^{\underline{a}}, 2^{\underline{a}}$ e $3^{\text {a }}$ série do ensino médio. A maioria trabalha com todas as turmas da escola. 
Gráfico 14 - Série que os professores atuam

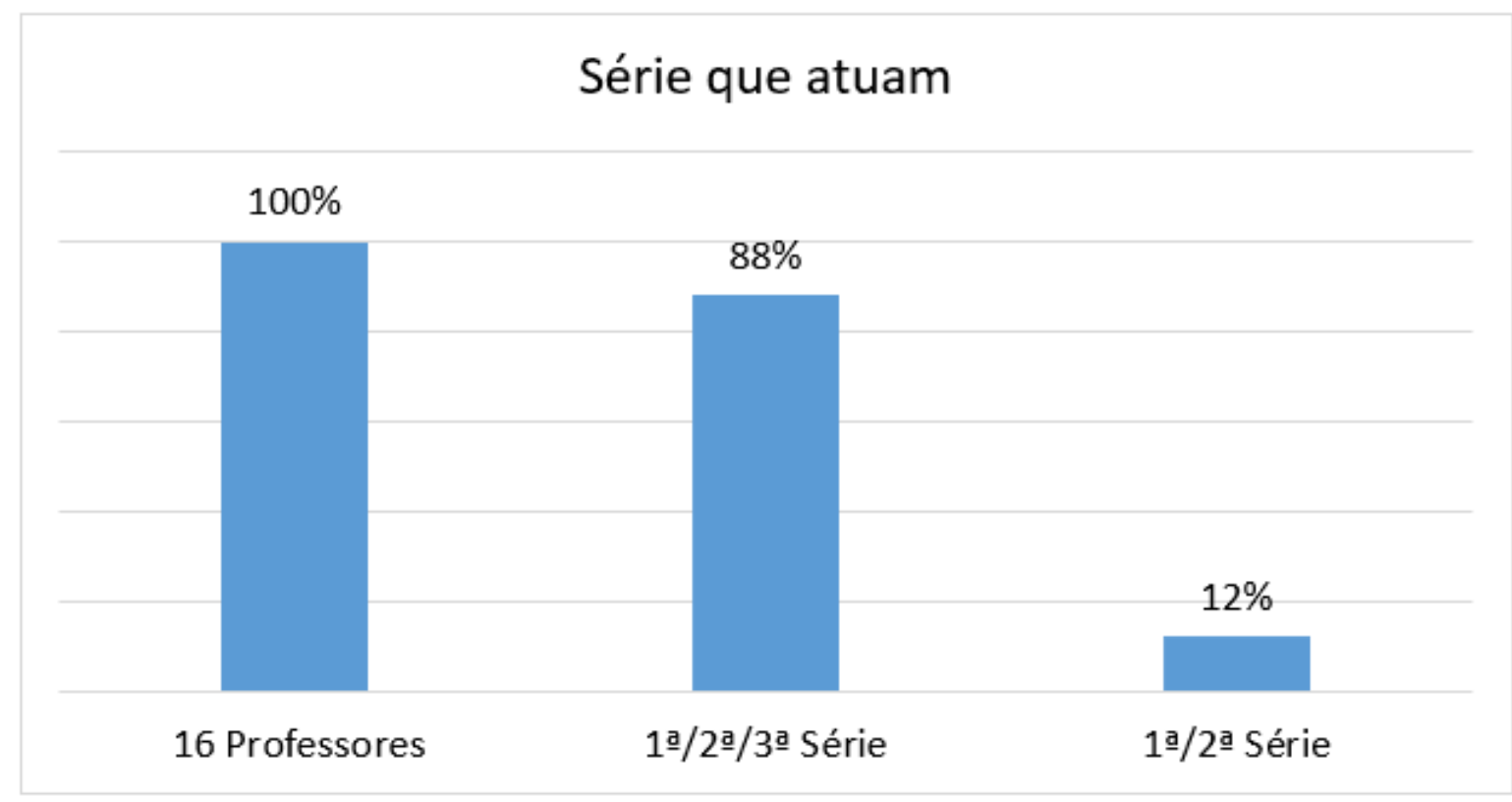

Fonte: dados da pesquisa (2019).

Em relação aos 2 professores que atuam na $1^{\underline{a}}$ e $2^{\underline{a}}$ série, pode ser por conta da complementação de carga horária em Sociologia, que acontece, pelo fato, dos professores efetivos suprirem as aulas e as restantes vão para ACT, desdobramentos de turmas e redução de carga horária de professor.

\section{CONSIDERAÇÕES FINAIS}

Os professores de Sociologia da Coordenadoria Regional de Educação de Canoinhas/SC são maioria do sexo masculino, e a faixa etária da maioria dos professores é entre 35 a 45 anos, sendo profissionais com uma certa maturidade. A maioria desses professores, residem nos municípios em que trabalham, assim não precisando deslocar-se até outros municípios.

Em relação a formação em Ciências Sociais/Sociologia, 12 professores são habilitados, esse professor também tem outras formações, como: Filosofia, História, Geografia, Pedagogia e Magistério. Nesse aspecto, de formação 14 professores têm especialização, 4 mestres e nenhum doutor. 
No tempo de atuação no magistério, desse professor é mediano, destacando que esses professores não tenham muito tempo de atuação na docência. Sendo levando em consideração a faixa etária desses professores e sua iniciação no magistério. Sobre a atuação desse professor, a grande maioria já lecionou ou ainda leciona outra disciplina nos níveis fundamentais e médios.

No que cabe a atuação desse professor em sociologia, é mediana, pois a grande maioria não tem mais do que 10 anos de atuação, sendo uma disciplina com poucas aulas, recente no currículo escolar e serve como opção para outros professores efetivos de disciplinas afins completarem sua carga horária, assim não dando espaço para muita atuação.

A grande maioria desses professores são efetivos. Essa efetivação é em Sociologia, Filosofia, História e Geografia. Esses professores atuam em duas ou mais escolas.

Ainda sobre a atuação, 7 professores tem a carga horária fechada em sociologia, ou seja, 40 horas, os demais complementam sua carga horária com outras disciplinas como: Filosofia, História e Geografia. Em relação as turmas trabalhadas, a maioria trabalha com as três turmas do ensino médio.

O perfil do professor de sociologia, já foi objeto de estudo de outras pesquisas, regionais, estaduais e federais, pelos autores: Mocelin e Raizer, Bodart e Silva e Raizer, Caregnato, Mocelin e Pereira. Sendo todos esses pesquisadores, professores de sociologia e interessados pela temática do ensino da sociologia no país.

Compreender o perfil do professor, é importante e necessário, pois o professor enquanto mediador do conhecimento é um indivíduo que irá colaborar com a formação e a preparação de seu aluno para a vivência em sociedade.

\section{REFERÊNCIAS}

BODART, C. N; SILVA, S. O perfil do professor brasileiro de sociologia do ensino médio e sua percepção da condição docente. Revista de Pós-Graduação em Ciências 
Sociais da UFRN. Inter-legere.no18 jan/jun de 2016. Disponível em: https://w.w.w periodicos.ufrn.br/interlegere/article/view/10820. Acesso 26 de out.2019.

CAREGNATO, C. E; CORDEIRO, V.C. Campo Cientifico-Acadêmico e a Disciplina de Sociologia na Escola. Educação e Realidade, v.39, p.39-47, 2014. Disponível em: http://www.scielo.br/pdf/edreal/v39n1/v39n1a04.pdf. Acesso 10 set.2019.

DURKHEIM, E. Educação e Sociologia. 11ª ed. São Paulo: Melhoramentos. 1978 JINKINGS.N.M.T.A sociologia em escolas de Santa Catarina. Revistainter-legere. Educação e Sociedade. $2013 . \quad$ Disponível em: https://w.w.w.periodicos.ufrn.br/interlegere/article/view/4407. Acesso 29 out.2019.

LAKATOS, E. M; Metodologia Científica. 4. ed. São Paulo: Atlas, 2001.

LAKATOS, E. M. Sociologia Geral / Eva Maria Lakatos, Marina de Andrade Marconi. - 7.ed. rev. e ampl. - 10.reimpr. - São Paulo: Atlas, 2010.

LIBÂNEO, J. C; OLIVEIRA, J. F; TOSCHI, M. S. Educação Escolar: política, estrutura e organização. São Paulo: Cortez, 2012.

MILLS, W. C. A imaginação sociológica. 4ae ed. Rio de Janeiro, Zahar, 1975.

MOCELIN, G.D. RAIZER, L. Ensino da sociologia no Rio Grande do Sul: Histórico da disciplina, formação do professor e finalidade pedagógica. Revista Brasileira de Sociologia.Vol.02.2014.

Disponível: http://www.sbsociologia.com.br/rbsociologia/index.php/rbs/article/view/92. Acesso 02 out.2019.

MOTA, K. C. C. S. Os lugares da sociologia na formação de estudantes do ensino médio: as perspectivas de professores. Revista Brasileira de Educação. n. 29, p. 88107, mai-ago, 2005. Disponível em: http://www.scielo.br/pdf/rbedu/n29/n29a08.pdf. Acesso 23 mar.2019. 
RAIZER. L. et al. O ensino da disciplina de Sociologia no Brasil: diagnóstico e desafios para a formação de professores. Revista Espaço Acadêmico- n.190- Março/2017. Disponível em: http://w.w.w.periodicos.uem.br/ojs/index.php/EspacoAcademico/article/view/35759. Acesso 26 out.2019.

RIOS, T. A. Compreender e ensinar: por uma docência da melhor qualidade. $2^{2}$ ed.SP.Cortez.2001.

RUSSCZYK.J; LEITÃO.L.R.S. A formação de professores em Sociologia para o ensino no Oeste Catarinense. Florianopólis, v.13,n.01, p.06-22jan/jun.2012. Disponível em: http://www.periodicos.udesc.br/index.php/percursos/article/view/2421. Acesso 26 mar.2019.

SILVA, I. F. A sociologia no ensino médio: os desafios institucionais e epistemológicos para a consolidação da disciplina. Revista Cronos, v. 8, n 2, p. 403-427, julhodezembro, $2007 . \quad$ Disponível em: https://w.w.w.periodicos.ufrn.br/cronos/article/download/1844. Acesso 26 mar.2019.

\section{APÊNDICE - REFERÊNCIA DE NOTA DE RODAPÉ}

4. Pesquisas sobre o ensino da Sociologia: Bodart e Silva (2016); Jinkings (2013); Mota (2005); Russczyk e Leitão (2012); Mocelin e Raizer (2013) e Raizer et al. (2017).

Enviado: Dezembro, 2020.

Aprovado: Janeiro, 2021. 